\title{
Quantitative Separation of the Bicarbonate from the Counter-cation Effect in Bean Plants
}

\author{
Luis A. Valdez-Aguilar ${ }^{1}$ \\ Centro de Investigación en Química Aplicada, Blvd. Enrique Reyna Hermosillo 140, Saltillo, Coah, \\ 25100, México \\ David William Reed \\ Department of Horticultural Sciences, Texas A\&M University, College Station, TX 77843-2133
}

John A. Cornell
Department of Statistics, University of Florida, 530 McCarty Hall C, P.O. Box 110339, Gainesville,
FL 32611-0339

ADDITIONAL INDEX wORDS. mixture experiment, potassium, rubidium, sodium, water quality

\begin{abstract}
The effect of $\mathrm{Rb}^{+}$and $\mathrm{Na}^{+}$as counter-cations of $\mathrm{HCO}_{3}{ }^{-}$was evaluated on bean (Phaseolus vulgaris $\mathrm{L}$. cv. Poncho) plants using mixture experiment statistical methodology in a series of experiments set up in a controlled environment chamber. Mixture experiments using three components $\left(\mathrm{Rb}^{+}, \mathrm{K}^{+}\right.$, and $\left.\mathrm{Na}^{+}\right)$or two components $\left(\mathrm{K}^{+}\right.$and $\mathrm{Na}^{+}$) were conducted to delineate the toxicity of $\mathrm{HCO}_{3}{ }^{-}$versus the counter-cation effect. The quantitative separation of the toxic effects was possible only when the individual stress had an additive effect when combined with the other stress. Potassium mixtures were used as reference for comparison with other mixtures because plants did not respond to $\mathrm{K}^{+}$, probably because it was included at a minimum concentration of $2.5 \mathrm{~mm} \mathrm{~K} \mathrm{~K}^{+}$or because it was supplied in the preestablishing solution. Rubidium caused a decrease in shoot dry weight (SDW), but SDW accumulation was even lower when $\mathrm{HCO}_{3}^{-}$was added to the $\mathrm{Rb}^{+}$solutions. However, $\mathrm{Rb}^{+}$was not included in follow-up experiments because the response of plants to $\mathrm{Rb}^{+}$was very similar to that of $\mathrm{Na}^{+}$. The toxic effect of $\mathrm{Na}^{+}$caused SDW to decrease at a rate of $3.7 \%$ per millimolar increase of $\mathrm{Na}^{+}$. However, the effect of $\mathrm{HCO}_{3}{ }^{-}$was dependent on its concentration, because at 2.5 mм $\mathrm{HCO}_{3}{ }^{-}$, the decrease in $\mathrm{SDW}$ was $12.7 \%$ per millimolar $\mathrm{HCO}_{3}^{-}$, whereas at 3.75, 5, and $5.65 \mathrm{~mm}$, the decrease was $11.0 \%, 7.8 \%$, and $10.7 \%$ per millimolar $\mathrm{HCO}_{3}^{-}$, respectively. At $7.5 \mathrm{~mm}^{\mathrm{HCO}_{3}}{ }^{-}$, the decrease in $\mathrm{SDW}$ was $4.2 \%$ to $8.2 \%$ per millimolar increase in $\mathrm{HCO}_{3}{ }^{-}$, respectively. The decreasing $\mathrm{HCO}_{3}{ }^{-}$rate may be explained by the nonadditive effect between $\mathrm{HCO}_{3}^{-}$and $\mathrm{Na}^{+}$at high alkalinity levels.
\end{abstract}

Saline and sodic soils cover $\approx 10 \%$ of arable land globally (Tanji, 1990). The predominant ions in these soils include: $\mathrm{HCO}_{3}{ }^{-}, \mathrm{CO}_{3}{ }^{2-}, \mathrm{Na}^{+}$, and $\mathrm{K}^{+}$(Shi and Wang, 2005). In addition to salinity, $\mathrm{HCO}_{3}{ }^{-}$and $\mathrm{CO}_{3}{ }^{2-}$ are the major soluble alkalis that cause alkalinity in water. Alkalinity measures the concentration of soluble alkalis and the buffering capacity of water, which results in neutralization of $\mathrm{H}^{+}$and increased $\mathrm{pH}$. Irrigation with water of high alkalinity may induce stunted growth (Pearce et al., 1999a, 1999b) as a result of decreased chlorophyll concentration in young leaves in many plant species (Alcántara et al., 1988; Campbell and Nishio, 2000; McCallister et al., 1989; Nikolic and Kastori, 2000). Decreased chlorophyll concentration has been attributed to impaired iron uptake (Bertoni et al., 1992) or decreased solubility of iron (Alcántara et al., 1988) at high soil solution $\mathrm{pH}$. High alkalinity may also inhibit growth of plants as a result of the direct effect of $\mathrm{HCO}_{3}$ on root growth and physiology (Alhendawi et al., 1997; Matkin and Petersen, 1971; Pearce et al., 1999b; Qi et al., 1994).

Most of the studies that investigate the effect of alkalinity on plant growth have been conducted using $\mathrm{Na}^{+}$as the countercation of $\mathrm{HCO}_{3}{ }^{-}$, although a lesser number of studies have used $\mathrm{K}^{+}$(Norvell and Adams, 2006). In these studies, the specific toxicity and osmotic effects of $\mathrm{Na}^{+}$have been ignored, probably

Received for publication 25 Oct. 2007. Accepted for publication 21 Feb. 2008. ${ }^{1}$ Corresponding author. E-mail: lavaldez@ciqa.mx.

We thank the Texas Ornamental Enhancement Program and The Fred C. Gloeckner Foundation, Inc. for grant support. under the assumption that plants have mechanisms to exclude $\mathrm{Na}^{+}$from uptake or translocation or because the concentrations of $\mathrm{Na}^{+}$were considered to be relatively low, although some plant species such as bean may be very sensitive to low concentrations of $\mathrm{Na}^{+}$(Marschner, 1995). In addition, the use of $\mathrm{K}^{+}$as counter-cation of $\mathrm{HCO}_{3}^{-}$may also interfere with experimental results as a result of the potential enhancement of $\mathrm{K}^{+}$nutrition and subsequently alter the response of plants to alkalinity (Kaya et al., 2002). Rubidium can also substitute $\mathrm{K}^{+}$, which in nature occurs mainly in acidic soils as a result of excessive $\mathrm{K}^{+}$leaching (Nyholm and Tyler, 2000). Because the counter-cations may prevent the delineation of the actual alkalinity effect, a series of mixture experiments using bean (Phaseolus vulgaris) as a model plant were conducted to quantitatively separate the effect of $\mathrm{HCO}_{3}{ }^{-}$from that of the counter-cation. Mixture experiments allow for the formulation of solutions in which only the proportions of the countercations can be modified while holding a constant $\mathrm{HCO}_{3}{ }^{-}$ concentration. Repeating the mixtures at different concentrations of $\mathrm{HCO}_{3}^{-}$, a mixture-amount experiment, allows the delineation of the $\mathrm{HCO}_{3}{ }^{-}$effect.

\section{Materials and Methods}

EXPT. 1: EFFECT OF MIXTURes OF $\mathrm{Rb}^{+}, \mathrm{K}^{+}$, AND $\mathrm{Na}^{+}$ON THE RESPONSE TO $\mathrm{HCO}_{3}{ }^{-}$. The objective of this experiment was to evaluate the effect of $\mathrm{Rb}^{+}, \mathrm{K}^{+}$, and $\mathrm{Na}^{+}$as counter-cations of $\mathrm{HCO}_{3}{ }^{-}$on the growth of bean plants. 'Poncho' pinto bean 
(Syngenta Biotechnology, Research Triangle Park, NC) seeds were germinated and kept at room temperature for $7 \mathrm{~d}$, and uniform seedlings with fully expanded cotyledonary leaves were transferred to $1.6-\mathrm{L}$ containers with one plant per container. Seedlings were allowed to establish for $7 \mathrm{~d}$ in a complete nutrient solution containing $\left(\mathrm{mg} \cdot \mathrm{L}^{-1}\right): 105 \mathrm{~N}, 15.5 \mathrm{P}$, $107 \mathrm{~K}, 90 \mathrm{Ca}, 24 \mathrm{Mg}, 44 \mathrm{~S}, 5 \mathrm{Fe}$ (Fe-DTPA), $0.02 \mathrm{Cu}, 0.05 \mathrm{Zn}$, $0.5 \mathrm{~B}, 0.11 \mathrm{Mo}$, and $0.65 \mathrm{Mn}$. The nutrient solution was prepared with $\mathrm{Ca}\left(\mathrm{NO}_{3}\right) \cdot 4 \mathrm{H}_{2} \mathrm{O}$ (Fisher Scientific, Pittsburgh, PA), $\left(\mathrm{NH}_{4}\right)_{2} \mathrm{SO}_{4}$ (Sigma, St. Louis, MO), $\mathrm{KNO}_{3}$ (Sigma), $\mathrm{KH}_{2} \mathrm{PO}_{4}$ (Sigma), $\mathrm{CaSO}_{4}$ (Sigma), $\mathrm{MgSO}_{4} \cdot 7 \mathrm{H}_{2} \mathrm{O}$ (Sigma), Fe-DTPA (Becker Underwood, Ames, IA), $\mathrm{H}_{3} \mathrm{BO}_{3}$ (Spectrum Chemical, Gardena, CA), MnCl. $4 \mathrm{H}_{2} \mathrm{O}$ (Matheson Coleman \& Bell Manufacturing Chemists, Norwood, OH), $\mathrm{ZnSO}_{4} \cdot 7 \mathrm{H}_{2} \mathrm{O}$ (Matheson Coleman \& Bell Manufacturing Chemists), $\mathrm{MoO}_{3}$ (Sigma), and $\mathrm{CuSO}_{4} \cdot 5 \mathrm{H}_{2} \mathrm{O}$ (Fisher Scientific, Fair Lawn, NJ).

The containers were covered with a coextruded black/white plastic sheet to prevent increasing temperature and light to affect the nutrient solution and roots. Air was filtered and bubbled constantly in each container for the duration of the experiment. Plants were grown in a controlled environment chamber (model M96-10-5K-0750A-277/480; Environmental Growth Chambers, Chagrin Falls, $\mathrm{OH}$ ) with temperature set at $27{ }^{\circ} \mathrm{C}$ day $/ 16^{\circ} \mathrm{C}$ night, $65 \%$ relative humidity, and daylength maintained from 0700 to $1900 \mathrm{HR}$. Average photosynthetically active radiation was $480 \mu \mathrm{mol} \cdot \mathrm{m}^{-2} \cdot \mathrm{s}^{-1}$.

The experiment was a simplex-centroid design mixture experiment augmented with three interior points yielding a total of 10 mixtures (Fig. 1); $\mathrm{HCO}_{3}{ }^{-}$was used as a process variable with two levels, 0 and $7.5 \mathrm{~mm}$. The components that varied in proportion were the counter-cations $\mathrm{Rb}^{+}, \mathrm{K}^{+}$, and $\mathrm{Na}^{+}$. The sum of the concentration of the $\mathrm{Rb}^{+}: \mathrm{K}^{+}: \mathrm{Na}^{+}$in the mixtures

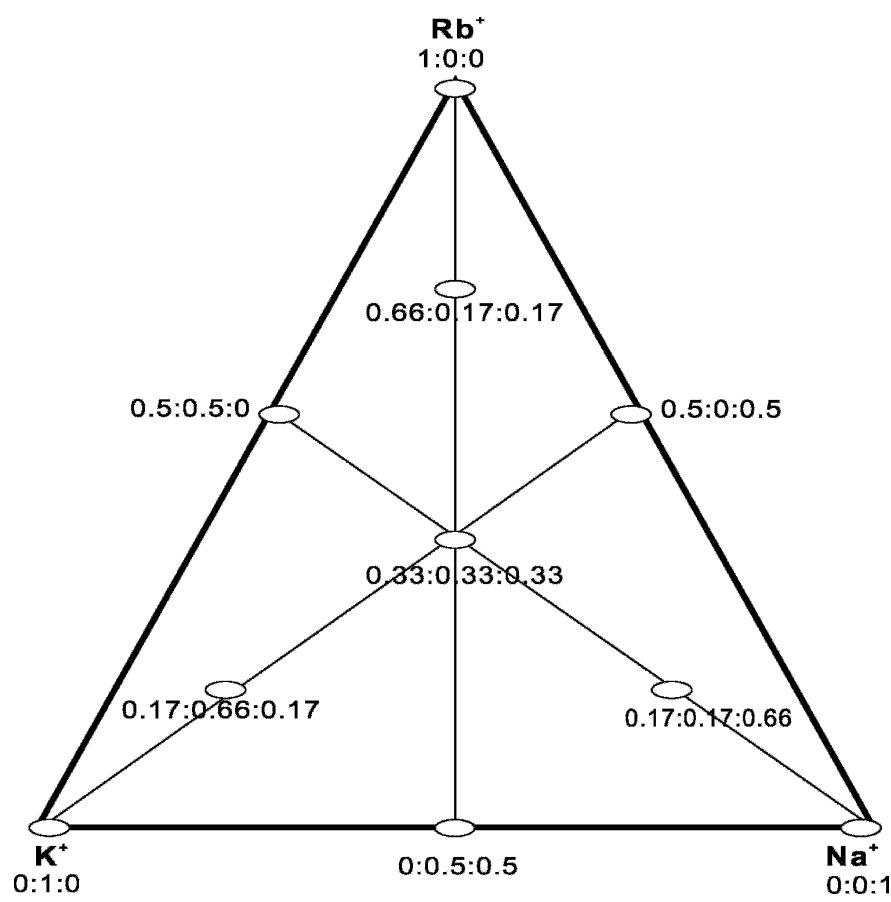

Fig. 1. Simplex centroid design augmented with three interior points. Each design point indicates the proportion of $\mathrm{Rb}^{+}: \mathrm{K}^{+}: \mathrm{Na}^{+}$in a mixture of $7.5 \mathrm{~mm}$ total cation concentration. The design was a mixture-amount experiment replicated at 0 and $7.5 \mathrm{mM} \mathrm{HCO}_{3}^{-}$. The axes for $\mathrm{Rb}^{+}, \mathrm{K}^{+}$, and $\mathrm{Na}^{+}$are the lines inside the triangle. was $7.5 \mathrm{~mm}$ and $\mathrm{HCO}_{3}{ }^{-}$concentration was held constant at 7.5 mm. The mixtures were prepared with $\mathrm{NaHCO}_{3}$ (Fisher Scientific), $\mathrm{KHCO}_{3}$ (Sigma), and $\mathrm{RbHCO}_{3}$. Rubidium bicarbonate was synthesized by bubbling pure $\mathrm{CO}_{2}$ gas into a solution of $\mathrm{RbOH}$ (Sigma) of a known concentration until $\mathrm{pH}$ was stabilized at 8.25 to 8.35 (R.H. Loeppert, personal communication). As a control, the experiment was repeated at $0 \mathrm{~mm} \mathrm{HCO}_{3}{ }^{-}$using $\mathrm{SO}_{4}{ }^{2-}$ as the anion and the solutions were prepared using $\mathrm{Na}_{2} \mathrm{SO}_{4}$ (Sigma), $\mathrm{K}_{2} \mathrm{SO}_{4}$ (Sigma), and $\mathrm{Rb}_{2} \mathrm{SO}_{4}$ (Sigma). Average initial solution $\mathrm{pH}$ and electrical conductivity (EC) was 6.34 and $2.18 \mathrm{dS} \cdot \mathrm{m}^{-1}$, respectively, for mixtures containing $0 \mathrm{mM} \mathrm{HCO}_{3}{ }^{-}$and 7.90 and $2.13 \mathrm{dS} \cdot \mathrm{m}^{-1}$, respectively, for mixtures containing $7.5 \mathrm{~mm} \mathrm{HCO}_{3}{ }^{-}$. The speciation of carbonates at $\mathrm{pH} 7.90$ is in equilibrium with a mole fraction of $\mathrm{HCO}_{3}{ }^{-}$of 0.968 ; thus, the actual concentration of $\mathrm{HCO}_{3}{ }^{-}$was $7.26 \mathrm{~mm}$.

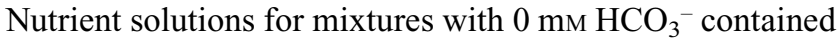
(mg. $\left.\mathrm{L}^{-1}\right): 195 \mathrm{~N}\left(6.5 \% \mathrm{NH}_{4}^{+}: 93.5 \% \mathrm{NO}_{3}^{-}\right), 181 \mathrm{Ca}^{2+}, 49 \mathrm{Mg}^{2+}$, and $120 \mathrm{~S}$ and were prepared with $\mathrm{Ca}\left(\mathrm{NO}_{3}\right) \cdot 4 \mathrm{H}_{2} \mathrm{O},\left(\mathrm{NH}_{4}\right)_{2} \mathrm{SO}_{4}$, and $\mathrm{Mg}\left(\mathrm{NO}_{3}\right)_{2} \cdot 6 \mathrm{H}_{2} \mathrm{O}$ (Fisher Scientific) (additional $\mathrm{S}$ was from the mixtures of $\mathrm{Na}_{2} \mathrm{SO}_{4}, \mathrm{~K}_{2} \mathrm{SO}_{4}$, and $\mathrm{Rb}_{2} \mathrm{SO}_{4}$ ). The mixtures with $7.5 \mathrm{~mm} \mathrm{HCO}_{3}{ }^{-}$had the same composition, except for $\mathrm{S}(14$ $\left.\mathrm{mg} \cdot \mathrm{L}^{-1}\right)$. All the nutrient solutions contained micronutrients as reported previously in the preculture solution. Potassium was not added to the nutrient solutions because it was a component of the mixtures. To test for hidden $\mathrm{K}^{+}$deficiency, leaf $\mathrm{K}^{+}$ concentration was determined by inductively coupled plasma mass spectrometry (SpectroCirus ${ }^{\mathrm{CCD}}$ Type: 76004527 4LOO76; Cirus, Fitchburg, MA) at experiment termination at the Soil, Water and Forage Testing Laboratory, Soil and Crop Sciences Department, Texas A\&M University, College Station.

At $7.5 \mathrm{~mm} \mathrm{HCO}_{3}{ }^{-}$, treatment solutions contained no $\mathrm{P}$ to avoid precipitation as a result of alkalinity. To supply all treatments with adequate $\mathrm{P}$, every $7 \mathrm{~d}$ for the duration of the study, solutions were replaced for $1 \mathrm{~d}$ with a $31 \mathrm{mg} \cdot \mathrm{L}^{-1} \mathrm{P}$ solution. This solution was prepared with $\left(\mathrm{NH}_{4}\right)_{2} \mathrm{HPO}_{4}$ (Sigma) and $\mathrm{NH}_{4} \mathrm{H}_{2} \mathrm{PO}_{4}$ (Sigma) to render a final $\mathrm{pH}$ of 6.3. The $0 \mathrm{~mm}$ $\mathrm{HCO}_{3}{ }^{-}$treatment solutions contained a constant $31 \mathrm{mg} \cdot \mathrm{L}^{-1} \mathrm{P}$. Average leaf $\mathrm{P}$ concentration in plants treated with $0 \mathrm{mM} \mathrm{HCO}_{3}{ }^{-}$ was $0.28 \% \pm 0.01 \%$ and in plants treated with $7.5 \mathrm{mM} \mathrm{HCO}_{3}^{-}$, it was $0.22 \% \pm 0.01 \%$. Thus, leaf $P$ concentration was within the sufficiency range $(0.2 \%$ to $0.4 \%)$ common for most plants, indicating that sufficient $\mathrm{P}$ was supplied by both protocols.

Each mixture treatment had four replicates randomly distributed in the growth chamber. The treatments were imposed 7 $\mathrm{d}$ after transplant and the plants were harvested $21 \mathrm{~d}$ later. At experiment termination, the shoots were washed, placed in individual paper bags, and dried in an oven at $75^{\circ} \mathrm{C}$ for $72 \mathrm{~h}$. Once dried, shoot dry weight (SDW) was measured. Shoot dry weight data were analyzed with Design Expert $^{\odot}$ version 6.0.4 software (Stat-Ease, Minneapolis, MN) computer program to obtain the three-dimensional response surface for the mixtures, analysis of variance, and the model that best fit the response. Model selection was based on highest $R^{2}$, adjusted $R^{2}$ close to the $R^{2}$, an adequate precision higher than 4.0 (a measurement of the signal-to-noise ratio), and the model with fewer terms. Shoot dry weight was also analyzed by multiple mean comparison with Tukey's test at $P<0.05$.

EXPT. 2: EFFECT OF $\mathrm{K}^{+}$: $\mathrm{Na}^{+}$BINARY MiXTURES ON THE RESPONSE TO $\mathrm{HCO}_{3}^{-}$. The objective of this experiment was to assess the effect of $\mathrm{K}^{+}: \mathrm{Na}^{+}$binary mixtures on the response of bean plants to $\mathrm{HCO}_{3}^{-}$. Rubidium was not selected as a 
component of the mixtures because in the previous experiment, it was observed that the response of bean plants was similar to that of $\mathrm{Na}^{+}$. The experimental design was a mixture-amount experiment with two components: $\mathrm{K}^{+}$and $\mathrm{Na}^{+}$, replicated at three total concentrations, $2.5,5$, and $7.5 \mathrm{~mm}$, with or without $\mathrm{HCO}_{3}{ }^{-}$.

'Poncho' pinto bean seeds were germinated as in Expt.1 and the seedlings were transferred to the hydroponic containers $7 \mathrm{~d}$ later. The preculture nutrient solution contained $\left(\mathrm{mg} \cdot \mathrm{L}^{-1}\right): 210$ $\mathrm{N}\left(10 \% \mathrm{NH}_{4}^{+}: 90 \% \mathrm{NO}_{3}{ }^{-}\right), 31 \mathrm{P}, 235 \mathrm{~K}^{+}, 200 \mathrm{Ca}^{2+}, 49 \mathrm{Mg}^{2+}$, and $65 \mathrm{~S}$ and was prepared with $\mathrm{Ca}\left(\mathrm{NO}_{3}\right) \cdot 4 \mathrm{H}_{2} \mathrm{O}, \mathrm{NH}_{4} \mathrm{NO}_{3}$ (Sigma), $\mathrm{Mg}\left(\mathrm{NO}_{3}\right)_{2} \cdot 6 \mathrm{H}_{2} \mathrm{O}$, and $\mathrm{MgSO}_{4} \cdot 7 \mathrm{H}_{2} \mathrm{O}$. Micronutrients, growing conditions, $\mathrm{K}^{+}$and $\mathrm{P}$ supply were as described in Expt. 1.

Mixtures with $\mathrm{HCO}_{3}{ }^{-}$were prepared with $\mathrm{NaHCO}_{3}$ and $\mathrm{KHCO}_{3}$, and mixtures with no $\mathrm{HCO}_{3}{ }^{-}$were prepared with $\mathrm{Na}_{2} \mathrm{SO}_{4}$ and $\mathrm{K}_{2} \mathrm{SO}_{4}$. To gain more precision in the model, five $\mathrm{K}^{+}: \mathrm{Na}^{+}$proportions-1:0, 0.75:0.25, 0.5:0.5, 0.25:0.75, and $0: 1$-were evaluated in each total concentration. All the mixtures contained $\mathrm{N}, \mathrm{Ca}^{2+}$, and $\mathrm{Mg}^{2+}$ as reported previously for the preculture solution and micronutrients for Expt. 1. Mixtures containing $2.5,5$, or $7.5 \mathrm{mM} \mathrm{HCO}_{3}{ }^{-}$had $32 \mathrm{mg} \cdot \mathrm{L}^{-1} \mathrm{~S}$, whereas in the $2.5,5$, or $7.5 \mathrm{~mm}$ total mixtures with $0 \mathrm{~mm}$ $\mathrm{HCO}_{3}{ }^{-}$, the concentration of $\mathrm{S}$ was 73,116 , and $153 \mathrm{mg} \cdot \mathrm{L}^{-1}$, respectively (additional $\mathrm{S}$ from $\mathrm{Na}_{2} \mathrm{SO}_{4}$ and $\mathrm{K}_{2} \mathrm{SO}_{4}$ ).

Each mixture treatment had four replicates, which were randomly distributed in the growth chamber. The treatments were imposed $7 \mathrm{~d}$ after transplant and the plants were harvested $21 \mathrm{~d}$ later. At experiment termination, SDW was measured and analyzed as in Expt. 1; the best fit equation for each response surface was selected as in Expt. 1.

Initial solution $\mathrm{pH}$ was $7.95,7.97$, and 8.00 for the mixtures containing $2.5,5$, or $7.5 \mathrm{mM}^{-\mathrm{HCO}_{3}}{ }^{-}$, respectively. The speciation of carbonates at $\mathrm{pH}$ of 7.95, 7.97, and 8.00 is in equilibrium with a mole fraction for $\mathrm{HCO}_{3}{ }^{-}$at $0.971,0.972$, and 0.973 , respectively; thus, the actual concentration of $\mathrm{HCO}_{3}{ }^{-}$for each of the total mixtures was $2.43,4.86$, and 7.30 $\mathrm{mM}$. Initial EC ranged from 1.63 to $1.73,1.90$ to 1.91 , and 2.00 to $2.10 \mathrm{dS} \cdot \mathrm{m}^{-1}$ for the mixtures containing $2.5,5$, or $7.5 \mathrm{~mm}$ $\mathrm{HCO}_{3}{ }^{-}$, respectively. In mixtures with $0 \mathrm{mM} \mathrm{HCO}_{3}{ }^{-}$, the initial solution $\mathrm{pH}$ ranged from 6.57 to 6.64 , and $\mathrm{EC}$ from 1.71 to 1.88 , 1.90 to 2.00 , and 1.99 to $2.10 \mathrm{dS} \cdot \mathrm{m}^{-1}$ for $2.5,5$, and $7.5 \mathrm{~mm}$ $\mathrm{HCO}_{3}{ }^{-}$, respectively.

EXPT. 3: EFFECT OF $\mathrm{K}^{+}: \mathrm{Na}^{+}$BINARY MiXTURES WITH A MINIMUM CONCENTRATION OF 2.5 MM $\mathbf{K}^{+}$. The objective of this experiment was to assess the effect of the $\mathrm{K}^{+}: \mathrm{Na}^{+}$binary mixtures on the response of bean plants to $\mathrm{HCO}_{3}{ }^{-}$. To eliminate the possibility of $\mathrm{K}^{+}$deficiency in the $\mathrm{Na}^{+}$pure blends, all the solutions contained a minimum concentration of $2.5 \mathrm{~mm} \mathrm{~K} \mathrm{~K}^{+}$. The experimental design was a mixture-amount experiment with two components: $\mathrm{K}^{+}$and $\mathrm{Na}^{+}$, and five levels of $\mathrm{HCO}_{3}{ }^{-}$ (mM): $0,1.88,3.75,5.65$, and 7.5. The $\mathrm{K}^{+}: \mathrm{Na}^{+}$proportions evaluated at each $\mathrm{HCO}_{3}{ }^{-}$concentration were 1:0, 0.75:0.25, $0.5: 0.5,0.25: 0.75$, and $0: 1$.

Mixtures with $\mathrm{HCO}_{3}{ }^{-}$were prepared with $\mathrm{NaHCO}_{3}$ and $\mathrm{KHCO}_{3}$ and the $0 \mathrm{mM} \mathrm{HCO}_{3}{ }^{-}$control mixtures were prepared with $\mathrm{Na}_{2} \mathrm{SO}_{4}$ and $\mathrm{K}_{2} \mathrm{SO}_{4}$. To avoid $\mathrm{K}^{+}$deficiency, especially in the $0 \mathrm{~K}^{+}$mixtures, all the solutions contained a baseline of 2.5 mM K ${ }^{+}$, supplied as $\mathrm{K}_{2} \mathrm{SO}_{4}$, which was not considered as part of the mixtures. Thus, the actual $\mathrm{K}^{+}: \mathrm{Na}^{+}$concentrations were (mM) $10: 0,8.13: 1.88,6.25: 3.75,4.28: 5.63$, and $2.5: 7.5$. The mixtures containing $0 \mathrm{mM} \mathrm{HCO}_{3}{ }^{-}$had $189,160,131,102$, and $73 \mathrm{mg} \cdot \mathrm{L}^{-1}$
$\mathrm{S}$ (additional $\mathrm{S}$ from $\mathrm{Na}_{2} \mathrm{SO}_{4}$ and $\mathrm{K}_{2} \mathrm{SO}_{4}$ ), respectively, whereas mixtures containing $\mathrm{HCO}_{3}{ }^{-}$had $32 \mathrm{mg} \cdot \mathrm{L}^{-1} \mathrm{~S}$. All the mixtures contained $\mathrm{N}, \mathrm{Ca}^{2+}, \mathrm{Mg}^{2+}$, and micronutrients as explained in previous experiments. Initial solution $\mathrm{pH}$ was $6.54,7.95,8.04,7.95$, and 8.14 for the mixtures containing 0 ,

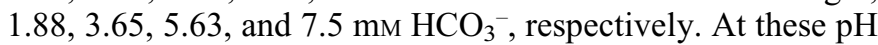
values, the speciation of carbonates is in equilibrium with a mole fraction for $\mathrm{HCO}_{3}{ }^{-}$at $0.971,0.975,0.971$, and 0.977 for the mixtures containing $1.88,3.65,5.63$, and $7.5 \mathrm{~mm} \mathrm{HCO}_{3}{ }^{-}$, respectively; thus, the actual concentration of $\mathrm{HCO}_{3}{ }^{-}$was 1.83 , $3.56,5.47$, and $7.33 \mathrm{~mm}$, respectively. Initial EC ranged from 2.1 to $2.5 \mathrm{dS} \cdot \mathrm{m}^{-1}$ for all the mixture treatments.

Germination of seeds and harvest were conducted as previously reported, whereas the preculture nutrient solution, growing conditions, and $\mathrm{P}$ supply were as described in Expt. 2. At experiment termination, SDW was measured and data analyzed as in Expts. 1 and 2.

\section{Results}

EXPT. 1: EFFECT OF MIXTURES OF $\mathrm{Rb}^{+}: \mathrm{K}^{+}: \mathrm{Na}^{+}$ON THE RESPONSE TO $\mathrm{HCO}_{3}{ }^{-}$. Shoot dry weight of plants was significantly affected by the $\mathrm{Rb}^{+}: \mathrm{K}^{+}: \mathrm{Na}^{+}$mixtures at $0 \mathrm{~mm} \mathrm{HCO}_{3}{ }^{-}$; however, at $7.5 \mathrm{mM} \mathrm{HCO}_{3}{ }^{-}$, there was a nonsignificant effect (Table 1). Eq. [1] is the best fit model $\left(R^{2}=0.714, P=0.0018\right)$ for the 0 and $7.5 \mathrm{mM} \mathrm{HCO}_{3}{ }^{-}$treatments (where $\mathrm{K}^{+}, \mathrm{Rb}^{+}$, and $\mathrm{Na}^{+}$ equal the proportion of each in the solution and must sum to 1.0; the $0 \mathrm{~mm} \mathrm{HCO}_{3}{ }^{-}$is solved with $\mathrm{HCO}_{3}{ }^{-}=-1$, and for $7.5 \mathrm{~mm}$ $\mathrm{HCO}_{3}{ }^{-}, \mathrm{HCO}_{3}{ }^{-}=+1$ ).

$$
\begin{aligned}
\mathrm{SDW}= & 3.97 \mathrm{~K}^{+}+3.47 \mathrm{Rb}^{+}+3.68 \mathrm{Na}^{+}-1.14 \mathrm{~K}^{+} \times \\
& \mathrm{HCO}_{3}^{-}-0.37 \mathrm{Rb}^{+} \times \mathrm{HCO}_{3}^{-}-0.25 \mathrm{Na}^{+} \times \mathrm{HCO}_{3}^{-} .
\end{aligned}
$$

The response surface for Eq. [1] is presented in Figure 2, in which the top plane corresponds to the response to the $0 \mathrm{~mm}$ $\mathrm{HCO}_{3}{ }^{-}$and the bottom plane corresponds to the $7.5 \mathrm{mM} \mathrm{HCO}_{3}{ }^{-}$.

Table 1. Effect of mixtures of varying proportions of $\mathrm{Rb}^{+}, \mathrm{K}^{+}$, and $\mathrm{Na}^{+}$ as counter-cations of $\mathrm{HCO}_{3}^{-}$on shoot dry weight of bean (Phaseolus vulgaris cv. Poncho) grown in hydroponics with a $7.5 \mathrm{~mm}$ total concentration of $\mathrm{Rb}^{+}, \mathrm{K}^{+}$, and $\mathrm{Na}^{+}$and two levels of $\mathrm{HCO}_{3}^{-}$

\begin{tabular}{llc}
\hline & \multicolumn{2}{c}{ Shoot dry $\mathrm{wt}^{\mathrm{z}}(\mathrm{g})$} \\
\cline { 2 - 3 } Mixtures $\left(\mathrm{Rb}^{+}: \mathrm{K}^{+}: \mathrm{Na}^{+}\right)$ & \multicolumn{2}{c}{$\mathrm{HCO}_{3}^{-}(\mathrm{mm})$} \\
\cline { 2 - 3 } Pure blends & $3.2 \mathrm{~b}$ & 7.5 \\
1: $0: 0$ & $4.9 \mathrm{a}$ & 2.7 \\
0: $1: 0$ & $4.1 \mathrm{~b}$ & 2.8 \\
0: $0: 1$ & & 3.3 \\
Binary blends & $4.7 \mathrm{a}$ & \\
0.5: $0.5: 0$ & $3.8 \mathrm{~b}$ & 3.2 \\
0.5: $0: 0.5$ & $4.6 \mathrm{ab}$ & 3.2 \\
0: $0.5: 0.5$ & & 3.7 \\
Centroid & $4.7 \mathrm{a}$ & 2.8 \\
0.33: $0.33: 0.33$ & & \\
Tertiary blends & $4.9 \mathrm{a}$ & 3.9 \\
0.66: $0.17: 0.17$ & $4.5 \mathrm{ab}$ & 3.2 \\
0.17: $0.66: 0.17$ & $3.5 \mathrm{~b}$ & 2.4 \\
0.17: $0.17: 0.66$ & & \\
\hline
\end{tabular}

${ }^{\mathrm{z}}$ Means within columns with the same letter indicates nonsignificant difference at $P \leq 0.05$ according to Tukey's multiple comparison test. 


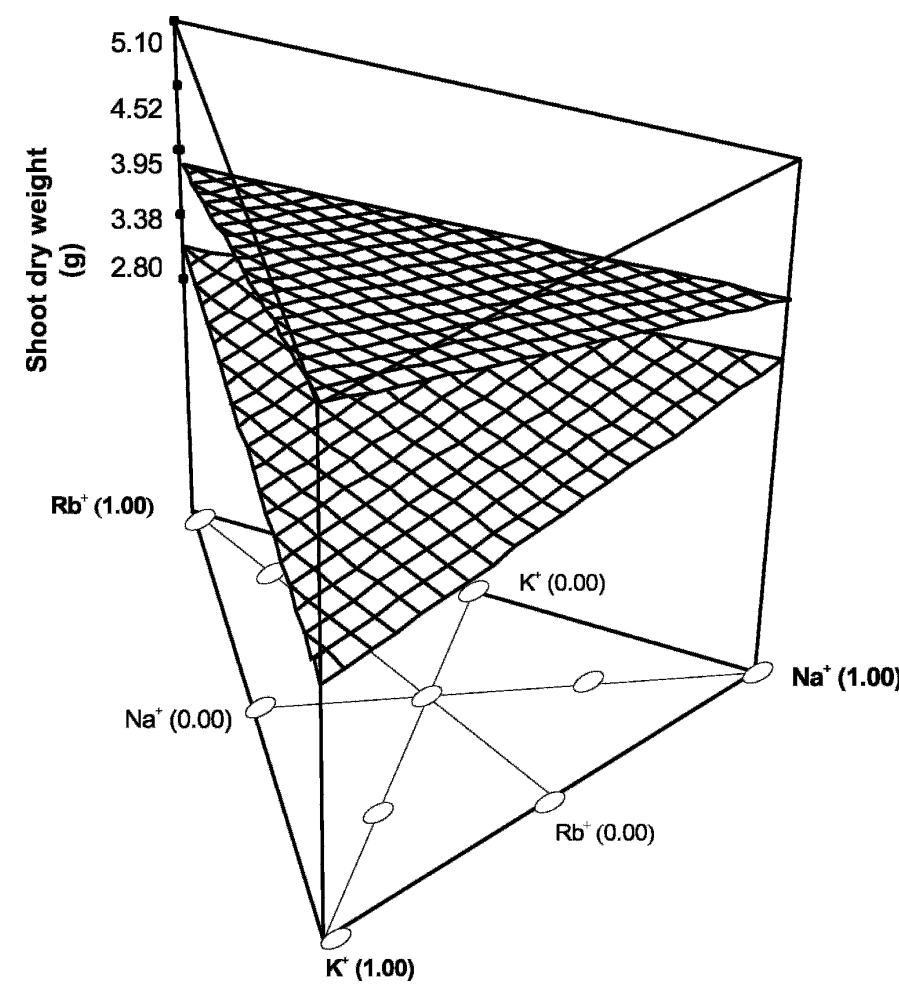

Fig. 2. Response surface of shoot dry weight of 'Poncho' bean (Phaseolus vulgaris) as affected by mixtures of $\mathrm{Rb}^{+}: \mathrm{K}^{+}: \mathrm{Na}^{+}$and $\mathrm{HCO}_{3}{ }^{-}$concentration. Top plane $=0 \mathrm{~mm} \mathrm{HCO}_{3}{ }^{-}$response surface; bottom plane $=7.5 \mathrm{~mm} \mathrm{HCO}_{3}{ }^{-}$ response surface. Models correspond to Eqs. [1], [2], and [3]

Eqs. [2] and [3] are the best fit models when $\mathrm{HCO}_{3}{ }^{-}$is 0 and 7.5 $\mathrm{mm}$, respectively (where $\mathrm{K}^{+}, \mathrm{Rb}^{+}$, and $\mathrm{Na}^{+}$equals the proportion of each in the solution and must sum to 1.0):

$$
\mathrm{SDW}=5.10 \mathrm{~K}^{+}+3.84 \mathrm{Rb}^{+}+3.93 \mathrm{Na}^{+} ; 0 \mathrm{mM} \mathrm{HCO}_{3}^{-}
$$

$$
\mathrm{SDW}=2.83 \mathrm{~K}^{+}+3.10 \mathrm{Rb}^{+}+3.43 \mathrm{Na}^{+} ; 7.5 \mathrm{mMHCO}_{3}^{-} .
$$

$\mathbf{0}$ мм $\mathrm{HCO}_{3}{ }^{-}$Mixtures. In the $0 \mathrm{~mm} \mathrm{HCO}_{3}{ }^{-}$mixtures (top response surface in Fig. 2), SDW decreased linearly when the proportion of $\mathrm{Na}^{+}$and $\mathrm{Rb}^{+}$increased. The highest SDW was estimated in the $\mathrm{K}^{+}$pure blend followed by the $\mathrm{Na}^{+}$and $\mathrm{Rb}^{+}$ pure blend (coefficients in Eq. [2]).

7.5 мм $\mathrm{HCO}_{3}^{-}$MixtURES. The response surface was relatively flat for the mixtures with $7.5 \mathrm{mM} \mathrm{HCO}_{3}$ (bottom response surface in Fig. 2). This is because there was very little difference in the toxicity of the counter-cations of $\mathrm{HCO}_{3}{ }^{-}$as indicated by the similar SDW (Table 1) and the comparable coefficients in Eq. [3].

EXPT. 2: EFFECT OF $\mathrm{K}^{+}: \mathrm{Na}^{+}$ BINARY MIXTURES ON THE RESPONSE OF BEAN Plants TO $\mathrm{HCO}_{3}^{-}$. The models that best fit the response to the $\mathrm{K}^{+}: \mathrm{Na}^{+}$mixtures were quadratic for the 2.5 (Fig. 3A) and $5 \mathrm{mM}$ (Fig.
3B) total mixtures and linear for the $7.5 \mathrm{mM}$ total mixture (Fig. $3 \mathrm{C})$. The best fitting models for the $2.5,5.0$, and $7.5 \mathrm{mM}$ total mixtures correspond to Eqs. [4], [5], and [6], respectively, with an $R^{2}=0.993(P=0.0002), 0.952(P=0.0098)$, and $0.894(P=$ $0.0025)$, respectively.

$$
\begin{aligned}
\mathrm{SDW}= & 3.68 \mathrm{~K}^{+}+2.23 \mathrm{Na}^{+}+4.15 \mathrm{~K}^{+} \times \mathrm{Na}^{+}-0.69 \mathrm{~K}^{+} \times \\
& \mathrm{HCO}_{3}^{-}-0.09 \mathrm{Na}^{+} \times \mathrm{HCO}_{3}^{-}-0.85 \mathrm{~K}^{+} \times \mathrm{Na}^{+} \times \\
& \mathrm{HCO}_{3}^{-} ; 2.5 \mathrm{mM} \text { total mixture. }
\end{aligned}
$$

$$
\begin{aligned}
\mathrm{SDW}= & 3.47 \mathrm{~K}^{+}+2.14 \mathrm{Na}^{+}+3.79 \mathrm{~K}^{+} \times \mathrm{Na}^{+}-0.84 \mathrm{~K}^{+} \times \\
& \mathrm{HCO}_{3}^{-}-0.12 \mathrm{Na}^{+} \times \mathrm{HCO}_{3}^{-}-1.77 \mathrm{~K}^{+} \times \mathrm{Na}^{+} \times \\
& \mathrm{HCO}_{3}^{-} ; 5 \mathrm{mM} \text { total mixture. }
\end{aligned}
$$

$$
\begin{aligned}
\mathrm{SDW}= & 4.25 \mathrm{~K}^{+}+2.43 \mathrm{Na}^{+}-1.18 \mathrm{~K}^{+} \times \mathrm{HCO}_{3}^{-}-0.15 \mathrm{Na}^{+} \times \\
& \mathrm{HCO}_{3}^{-} ; 7.5 \mathrm{mM} \text { total mixture. }
\end{aligned}
$$

0 мм $\mathrm{HCO}_{3}{ }^{-}$. When the concentration of $\mathrm{HCO}_{3}{ }^{-}$was at $0 \mathrm{~mm}$, SDW decreased as the proportion of $\mathrm{Na}^{+}$increased in all the mixtures regardless of the total mixture concentration (top lines of Fig. 3A-C). In the 2.5 and $5 \mathrm{~mm}$ total mixtures, the decrease was more pronounced when the proportion of $\mathrm{Na}^{+}$was greater than 0.5 (Fig. 3A-B). In the $7.5 \mathrm{~mm}$ total mixture, there was a liner decrease, suggesting a constant negative effect resulting from a higher $\mathrm{Na}^{+}$proportion (top line of Fig. 3C).

Mixtures containing $\mathrm{HCO}_{3}{ }^{-}$. Bicarbonate caused a marked decrease in SDW as indicated by the separation between the top and bottom regression lines of Figure 3 . Decreased SDW resulting from $\mathrm{HCO}_{3}{ }^{-}$ranged from $7 \%$ to $44 \%$ depending on the total concentration and proportion of $\mathrm{K}^{+}: \mathrm{Na}^{+}$. In Figures $3 \mathrm{~A}$ and $3 \mathrm{~B}$, the separation between top and bottom regression lines is almost equidistant when the proportion of $\mathrm{Na}^{+}$was less than 0.5 . However, the regression lines appear closer at higher proportions, suggesting that $\mathrm{Na}^{+}$and $\mathrm{HCO}_{3}{ }^{-}$are more detrimental. In mixtures containing $7.5 \mathrm{~mm}$ $\mathrm{HCO}_{3}{ }^{-}$(bottom line of Fig. $3 \mathrm{C}$ ), the effect of increasing $\mathrm{Na}^{+}$ was not apparent.

EXPT. 3: EFFECT OF $\mathrm{K}^{+}$: $\mathrm{Na}^{+}$BINARY MIXTURES WITH AT LEAST 2.5 Mм $\mathrm{K}^{+}$CONCENTRATion. The final equation, including the

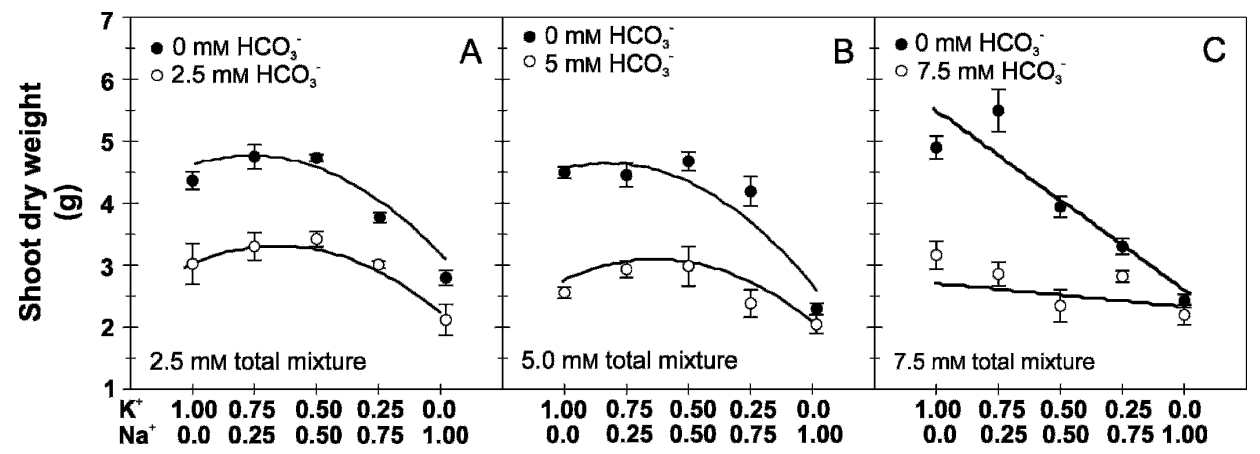

Fig. 3. Effect of 2.5, 5, and $7.5 \mathrm{~mm}$ total mixtures of varying $\mathrm{K}^{+}$and $\mathrm{Na}^{+}$proportions at two levels of $\mathrm{HCO}_{3}{ }^{-}$ on shoot dry weight of 'Poncho' bean (Phaseolus vulgaris). Models correspond to Eqs. [4], [5], and [6], respectively. Bars represent SE $(n=4)$. 
process variable that best fit the response to the $\mathrm{K}^{+}: \mathrm{Na}^{+}$mixtures in all the $\mathrm{HCO}_{3}{ }^{-}$concentrations, was $\left(R^{2}=0.927 ; P<0.0001\right)$ :

$$
\begin{aligned}
\mathrm{SDW}= & 5.70 \mathrm{~K}^{+}+4.02 \mathrm{Na}^{+}+0.06 \mathrm{Na}^{+} \times \mathrm{HCO}_{3}^{-}+0.50 \mathrm{~K}^{+} \times \\
& \mathrm{HCO}_{3}^{-}-0.20 \mathrm{Na}^{+} \times\left(\mathrm{HCO}_{3}^{-}\right)^{2}-0.43 \mathrm{~K}^{+} \times \\
& \left(\mathrm{HCO}_{3}^{-}\right)^{2}+0.02 \mathrm{Na}^{+} \times\left(\mathrm{HCO}_{3}^{-}\right)^{3}+0.04 \mathrm{~K}^{+} \times\left(\mathrm{HCO}_{3}^{-}\right)^{3} .
\end{aligned}
$$

Independent analysis of the $\mathrm{HCO}_{3}{ }^{-}$concentrations, in terms of the actual factors, demonstrated that the best fitting models at the $0,1.88,3.75,5.65$, and $7.5 \mathrm{mM}^{-} \mathrm{HCO}_{3}{ }^{-}$were the linear blending models of Eqs. [8] to [12], respectively (Fig. 4).

$$
\mathrm{SDW}=5.65 \mathrm{~K}^{+}+4.00 \mathrm{Na}^{+} ; 0 \mathrm{mM} \mathrm{HCO}-
$$

$$
\mathrm{SDW}=5.57 \mathrm{~K}^{+}+3.77 \mathrm{Na}^{+} ; 1.88 \mathrm{mM} \mathrm{HCO}-
$$

$$
\mathrm{SDW}=3.34 \mathrm{~K}^{+}+2.14 \mathrm{Na}^{+} ; 3.75 \mathrm{mM} \mathrm{HCO}-
$$

$$
\mathrm{SDW}=2.25 \mathrm{~K}^{+}+2.00 \mathrm{Na}^{+} ; 5.65 \mathrm{mM} \mathrm{HCO}_{3}^{-}
$$

$$
\mathrm{SDW}=2.16 \mathrm{~K}^{+}+2.14 \mathrm{Na}^{+} ; 7.5 \mathrm{mM} \mathrm{HCO}-\text {. }
$$

O мм $\mathbf{H C O}_{3}{ }^{-}$. Similar to Expt. 2, in solutions with $0 \mathrm{~mm}$ $\mathrm{HCO}_{3}{ }^{-}$, SDW decreased as the proportion of $\mathrm{Na}^{+}$increased (Fig. 4A). When compared with the $1: 0 \mathrm{~K}^{+}: \mathrm{Na}^{+}$mixture, the decrease was $7 \%, 15 \%, 22 \%$, and $29 \%$ when the proportion of $\mathrm{Na}^{+}$increased to $0.25,0.5,0.75$, and 1.0 , respectively.

Mixtures Containing $\mathrm{HCO}_{3}{ }^{-}$. The trend of decreased SDW with increasing proportion of $\mathrm{Na}^{+}$in mixtures with $0 \mathrm{mM} \mathrm{HCO}_{3}{ }^{-}$ was also exhibited when plants were grown in solutions
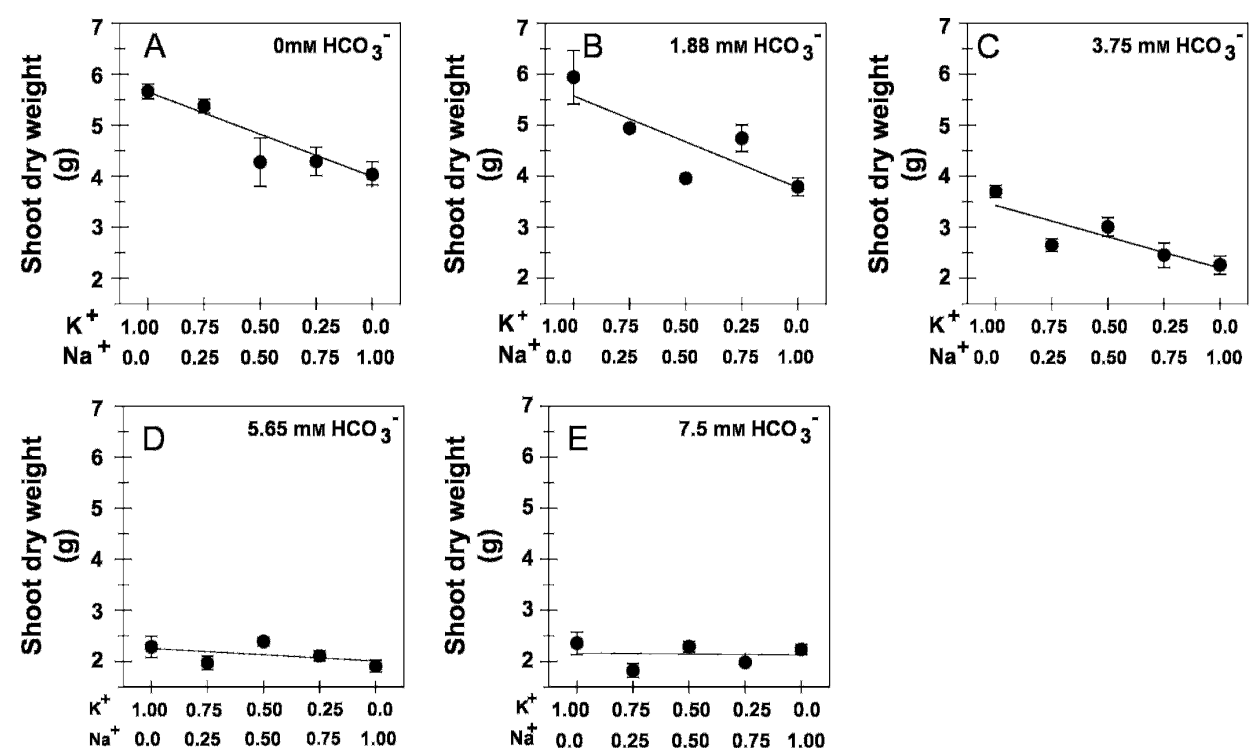

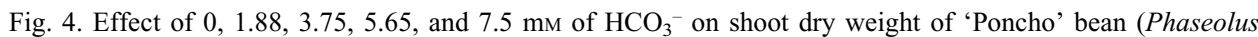
vulgaris) as affected by mixtures of varying $\mathrm{K}^{+}$and $\mathrm{Na}^{+}$proportions. Models correspond to Eqs. [8] to [12], respectively. Total $\mathrm{K}^{+}+\mathrm{Na}^{+}$mixture is $7.5 \mathrm{~mm}$. Bars represent SE $(\mathrm{n}=4)$. containing 1.88 and $3.75 \mathrm{~mm}^{-\mathrm{HCO}_{3}}{ }^{-}$(Fig. 4B-C) (comparable slopes). However, when the solutions had 5.65 and $7.5 \mathrm{~mm}$ $\mathrm{HCO}_{3}^{-}$, increasing proportions of $\mathrm{Na}^{+}$apparently did not further decrease SDW (Fig. 4D-E).

\section{Discussion}

The addition of $\mathrm{HCO}_{3}{ }^{-}$to the mixtures caused a decrease in SDW, demonstrating the detrimental effect of alkalinity on bean plants. However, $\mathrm{Rb}^{+}$and $\mathrm{Na}^{+}$were also associated with a decrease in SDW, suggesting that these counter-cations may also detrimentally affect plant growth in addition to $\mathrm{HCO}_{3}{ }^{-}$ when they are mixed together. Similar results were demonstrated by Navarro et al. (2000), who reported that dry weight of tomato plants treated with $\mathrm{NaCl}$ was reduced, but the addition of $\mathrm{HCO}_{3}{ }^{-}$promoted a more pronounced negative effect than $\mathrm{NaCl}$ salinity alone.

The response to $\mathrm{HCO}_{3}{ }^{-}$observed in the present experiments was independent of the $\mathrm{K}^{+}$concentration in the nutrient solutions. As indicated previously, the plants grown in the $\mathrm{Rb}^{+}$or $\mathrm{Na}^{+}$pure blends in Expts. 1 and 2 did not receive $\mathrm{K}^{+}$ during the experimental period, raising the question as to what extent SDW was affected by the $\mathrm{K}^{+}$deprivation. This was ruled out because leaves sampled at experiment termination form plants grown in the $\mathrm{Rb}^{+}$and $\mathrm{Na}^{+}$pure blends had leaf $\mathrm{K}^{+}$ concentrations of $1.42 \%$ and $1.58 \%$ in $0 \mathrm{~mm} \mathrm{HCO}_{3}{ }^{-}$-exposed plants. Leaf $\mathrm{K}^{+}$tissue concentrations were at the lower level of the sufficiency range and were above the deficiency range for most crops (Bould et al., 1984). Our assumption that $\mathrm{K}^{+}$had no effect is also supported by Expt. 3 (in which all the solutions, including the $\mathrm{Na}^{+}$pure blend, contained a minimum of $2.5 \mathrm{~mm}$ $\mathrm{K}^{+}$), since the effect on SDW was comparable to that of the previous experiments, as observed in the regression lines of Figures 4A and 4D (Expt. 3). The regression lines of Figures 4A and D show comparable tendencies as the regression lines of Figure 3C (Expt. 2) and estimated SDW surface heights above the $\mathrm{K}^{+}: \mathrm{Na}^{+}$edge of the triangular region in Figure 2 (Expt. 1). Potassium sufficiency, despite the deprivation during the experimental period, was probably the result of sufficient $\mathrm{K}^{+}$accumulation when the plants were precultured in $\mathrm{K}^{+}$containing solutions or a short exposure to $\mathrm{K}^{+}$-free solutions (21 d). The $\mathrm{K}^{+}$accumulated during preculture may also have been redistributed to developing organs during the deprivation period, allowing plant growth (Sudharmai and Padmaja, 1997).

In Expt. 1, the highest SDW of plants grown in the $0 \mathrm{~mm} \mathrm{HCO}_{3}{ }^{-}$ mixtures (top response surface in Fig. 2) was estimated to occur when they were grown in the $\mathrm{K}^{+}$pure blend. Plants grown in the $\mathrm{Rb}^{+}$and $\mathrm{Na}^{+}$pure blends had a decrease in biomass accumulation of $25 \%$ and $23 \%$, respectively, compared with those grown in the $\mathrm{K}^{+}$pure blend. However, there was very little difference between the toxicity of the 
counter-cations at $7.5 \mathrm{~mm} \mathrm{HCO}_{3}^{-}$(bottom response surface in Fig. 2). The decrease in the position of the $7.5 \mathrm{~mm} \mathrm{HCO}_{3}^{-}$ response surface when compared with the $0 \mathrm{~mm} \mathrm{HCO}_{3}^{-}$ response surface in Figure 2 represents the toxicity effect of $\mathrm{HCO}_{3}{ }^{-}$. On average, this toxicity effect caused a $24 \%$ decrease in SDW over all the design points evaluated. However, the decrease in SDW depended on the predominant counter-cation, because it was of $19 \%, 13 \%$, and $45 \%$ in the $\mathrm{Rb}^{+}, \mathrm{Na}^{+}$, and $\mathrm{K}^{+}$ pure blends, respectively.

In Expts. 2 and 3, $\mathrm{Rb}^{+}$was not included in the study because the decrease in SDW was comparable to that of $\mathrm{Na}^{+}$. In Expt. 2, at $0 \mathrm{~mm} \mathrm{HCO}_{3}{ }^{-}$, the $\mathrm{Na}^{+}$pure blend $\left(0: 1 \mathrm{~K}^{+}: \mathrm{Na}^{+}\right)$caused a decrease in SDW of $47 \%, 47 \%$, and $52 \%$ in the $2.5,5$, and 7.5 mu total mixtures, respectively, whereas in mixtures containing $\mathrm{HCO}_{3}{ }^{-}$, the decrease was of $28 \%, 23 \%$, and $26 \%$, respectively (Fig. 3). In Expt. 3, at $0 \mathrm{~mm} \mathrm{HCO}_{3}{ }^{-}$, SDW decreased 7\%, 15\%, $22 \%$, and $29 \%$, when the proportion of $\mathrm{Na}^{+}$was increased to $0.25,0.5,0.75$, and 1.0 , respectively (Fig. 4A). However, in mixtures containing $\mathrm{HCO}_{3}{ }^{-}$, the decrease associated with increasing $\mathrm{Na}^{+}$was observed when the plants were grown in solutions containing 1.88 and $3.75 \mathrm{~mm} \mathrm{HCO}_{3}^{-}$(Fig. 4B-C) (comparable slopes). When the solutions contained 5.65 and 7.5 $\mathrm{mm} \mathrm{HCO}_{3}{ }^{-}$, increasing the proportions of $\mathrm{Na}^{+}$did not further decrease SDW, as suggested by the near to zero slope in the regression lines of Figures 4D and 4E.

The largest SDW was observed in plants grown in $\mathrm{K}^{+}$pure blends, indicating that there was no $\mathrm{K}^{+}$toxicity. Thus, the $\mathrm{K}^{+}$ pure blends can be used as a reference solution, similar to a control, because there was no toxic effect and because $\mathrm{K}^{+}$ concentration was close to that of Hoagland's nutrient solution. Assuming that the $\mathrm{K}^{+}$pure blend is the control solution, it is convenient to transform or reparameterize Eqs. [2] and [3] by removing the $\mathrm{K}^{+}$term from the models and substituting a constant or intercept term (Cornell, 2002). At $0 \mathrm{mM} \mathrm{HCO}_{3}^{-}$, the reparameterized model for Eq. [2], which was $\mathrm{SDW}=5.10 \mathrm{~K}^{+}+$ $3.84 \mathrm{Rb}^{+}+3.93 \mathrm{Na}^{+}$, is:

$$
\mathrm{SDW}=5.10-1.26 \mathrm{Rb}^{+}-1.17 \mathrm{Na}^{+} .
$$

At the $7.5 \mathrm{~mm}$ level of $\mathrm{HCO}_{3}{ }^{-}$, the reparameterized model for Eq. [3], which was $\mathrm{SDW}=2.83 \mathrm{~K}^{+}+3.10 \mathrm{Rb}^{+}+3.43 \mathrm{Na}^{+}$, is:

$$
\mathrm{SDW}=2.83+0.27 \mathrm{Rb}^{+}+0.60 \mathrm{Na}^{+} .
$$

The difference between the intercepts of Eqs. [14] and [13] $(2.83-5.10=-2.27)$ represents the effect of replacing $0 \mathrm{~mm}$ $\mathrm{HCO}_{3}{ }^{-}$with $7.5 \mathrm{~mm} \mathrm{HCO}_{3}{ }^{-}$, which is the pure $\mathrm{HCO}_{3}{ }^{-}$effect. The coefficients for $\mathrm{Na}^{+}(-1.17)$ and $\mathrm{Rb}^{+}(-1.26)$ in solutions containing $0 \mathrm{~mm} \mathrm{HCO}_{3}{ }^{-}$(Eq. [13]) represent the pure $\mathrm{Na}^{+}$and $\mathrm{Rb}^{+}$effects, but the coefficients of Eq. [14] for $\mathrm{Na}^{+}(+0.60)$ and $\mathrm{Rb}^{+}(+0.27)$ consider the interaction between the countercations and $\mathrm{HCO}_{3}^{-}$.

In this article, we use the term additive, as defined by Welfare et al. (1996), when the effect of the combination of two stresses is equal to the sum of the effect of each individual stress, the term synergistic when it is greater than the sum of the two stresses, and the term antagonistic when it is lower than the sum of the two stresses. To visualize this in Expt. 1, let us position an imaginary third plane between the two planes of Figure 2, where the heights of the vertices of the third plane are midway between the heights of the vertices of the 0 and $7.5 \mathrm{~mm}$ $\mathrm{HCO}_{3}{ }^{-}$planes. Since plane 3 would be twisted because
$\mathrm{HCO}_{3}{ }^{-}$differently affects the response to $\mathrm{K}^{+}, \mathrm{Rb}^{+}$, and $\mathrm{Na}^{+}$, then one or more of the crossproduct terms in Eq. [1] is significant (nonzero) and we say that the presence of $\mathrm{HCO}_{3}{ }^{-}$ interacts with the linear blending properties of the cations and that the effect is nonadditive. If raising $\mathrm{HCO}_{3}{ }^{-}$from 0 to 7.5 $\mathrm{mM}$ would have had planes separated by the same distance, then $\mathrm{HCO}_{3}^{-}$and the counter-cations would have had an additive effect. Additionally, if the interaction between $\mathrm{HCO}_{3}{ }^{-}$and $\mathrm{Rb}^{+}$or $\mathrm{Na}^{+}$was additive, then the total stress of the mixtures would be equal to the sum of the pure $\mathrm{HCO}_{3}{ }^{-}$ effect $(-2.27)$ with the pure effect for the respective countercation $\left(\mathrm{Na}^{+}=-1.17\right.$ and $\left.\mathrm{Rb}^{+}=-1.26\right)$. Because the $\mathrm{Na}^{+}$and $\mathrm{Rb}^{+}$ coefficients of Eq. [14] are not equal to the sum of the $\mathrm{HCO}_{3}{ }^{-}$ and the $\mathrm{Na}^{+}$effect $(-2.27-1.17 \neq 0.27)$ or the $\mathrm{HCO}_{3}{ }^{-}$and the $\mathrm{Rb}^{+}$effect $(-2.27-1.26 \neq 0.60)$, then the conclusion is that the combined effect of $\mathrm{HCO}_{3}{ }^{-}$plus the counter-cation effect was not additive.

The nonadditive interaction detected in Expt. 1 indicates that the stress caused by $\mathrm{HCO}_{3}^{-}$and that of the counter-cation reaches a point that it is not equal to the sum of the individual stresses. Shi and Sheng (2005) mentioned that salinity and alkalinity stress cause a reciprocal enhancement of its individual components, suggesting that their effects are synergistic. Our results, however, indicate that for bean, the stress caused by $\mathrm{Rb}^{+}$or $\mathrm{Na}^{+}$is indeed enhanced by the addition of $\mathrm{HCO}_{3}^{-}$, but they were not additive or synergistic at the concentrations evaluated in Expt. 1. In Expt. 2 (Fig. 3C) and Expt. 3 (Figs. 4A and 4D), the same trends were observed when similar concentrations of $\mathrm{HCO}_{3}{ }^{-}$were used. Welfare et al. (1996) explained the possible mechanisms for a nonadditive effect of salinity and ozone toxicity in alfalfa indicating that the affect was related to physiological processes such as the stomatal closure, which in turn decreased photosynthesis rate and yield. The authors suggest that stomatal closure also decreases the entry of ozone into the mesophyll and transpiration rate, thereby limiting the root uptake of salts and thus, the effect of salinity. Because the effects of $\mathrm{HCO}_{3}^{-}, \mathrm{Rb}^{+}$, and $\mathrm{Na}^{+}$when they are mixed were nonadditive, it is impossible to quantitatively determine to what extent each ion is exerting its effect. Thus, the real separation of the $\mathrm{HCO}_{3}{ }^{-}$effect from its counter-cation effect should be addressed only when both effects are additive and can be estimated numerically.

The additive effects of $\mathrm{Na}^{+}$and $\mathrm{HCO}_{3}{ }^{-}$on $\mathrm{SDW}$ were observed only when $\mathrm{HCO}_{3}{ }^{-}$concentration was $3.75 \mathrm{~mm}$ or less as inferred by the parallel lines in Figure $4 \mathrm{~A}-\mathrm{C}$, which indicate comparable slopes and equidistant regression lines (see Eqs. [15] to [17]). When $\mathrm{HCO}_{3}{ }^{-}$concentration was 0 and $1.88 \mathrm{~mm}$, there was only a $\mathrm{Na}^{+}$effect (Fig. 4A), but when the concentration of $\mathrm{HCO}_{3}{ }^{-}$was increased to $3.75 \mathrm{~mm}$, there was both $\mathrm{Na}^{+}$ and $\mathrm{HCO}_{3}{ }^{-}$effects (Fig. 4C). When $\mathrm{HCO}_{3}{ }^{-}$concentration was $5.66 \mathrm{~mm}$, there was only a $\mathrm{HCO}_{3}{ }^{-}$effect, but with $7.5 \mathrm{~mm}$ neither $\mathrm{HCO}_{3}{ }^{-}$nor $\mathrm{Na}^{+}$increased the toxic effects (Fig. 4D). Therefore, the pure $\mathrm{Na}^{+}$effect can be estimated when $\mathrm{HCO}_{3}{ }^{-}$ was at $0,1.88$, and $3.75 \mathrm{~mm}$, whereas the pure $\mathrm{HCO}_{3}{ }^{-}$effect can be estimated when the concentration was $1.88,3.75$, and 5.66 mm. Thus, to separate the effects of $\mathrm{Na}^{+}$from that of $\mathrm{HCO}_{3}{ }^{-}$ when both were mixed in the solutions, the analysis should be only when both affected plant growth. Using the reparameterized models of Eqs. [8] to [10], which are Eqs. [15] to [17], allows for the estimation of the $\mathrm{HCO}_{3}{ }^{-}$effect by comparing the intercepts and the estimation of the $\mathrm{Na}^{+}$effect using the coefficients. 


$$
\begin{array}{r}
\mathrm{SDW}=5.65-1.65 \mathrm{Na}^{+} ; 0 \mathrm{mM} \mathrm{HCO}- \\
\mathrm{SDW}=5.57-1.80 \mathrm{Na}^{+} ; 1.88 \mathrm{mM} \mathrm{HCO}_{3}^{-} \\
\mathrm{SDW}=3.34-1.20 \mathrm{Na}^{+} ; 3.75 \mathrm{mM} \mathrm{HCO}_{3}^{-}
\end{array}
$$

Thus, $\mathrm{HCO}_{3}{ }^{-}$at $3.75 \mathrm{~mm}$ caused a 2.31-g decrease in SDW (3.34 to 5.65), whereas $\mathrm{Na}^{+}$at $7.5 \mathrm{~mm}$ caused, on average, a decrease of $1.55 \mathrm{~g}[(1.65+1.80+1.20) / 3]$. Therefore, $\mathrm{Na}^{+}$is responsible for a SDW decrease of $0.21 \mathrm{~g}$ per $\mathrm{mm}$ increase of $\mathrm{Na}^{+}(1.55 / 7.5)$ and $\mathrm{HCO}_{3}{ }^{-}$is responsible for a SDW decrease of $0.62 \mathrm{~g}$ per mм increase of $\mathrm{HCO}_{3}^{-}(2.31 / 3.75)$. These figures represent a $3.7 \%$ decrease in SDW $[(0.21 / 5.65) \times 100]$ per $\mathrm{mm}$ increase of $\mathrm{Na}^{+}$and an $11.0 \%$ decrease in SDW $[(0.62 / 5.65) \times$ 100] per mM increase of $\mathrm{HCO}_{3}^{-}$, indicating that $\mathrm{HCO}_{3}^{-}$is responsible for a larger decrease in SDW than $\mathrm{Na}^{+}$. Data form Expt. 2 is consistent with this approach. As observed in Figure $3 \mathrm{~A}$, the regression lines show a tendency to be parallel and equidistant, suggesting that the toxicity of the $\mathrm{HCO}_{3}{ }^{-}$and $\mathrm{Na}^{+}$ stresses is additive when the concentration of the former is low $(2.5 \mathrm{~mm})$. However, the equidistance between regression lines tends to be lost at 5 and $7.5 \mathrm{~mm} \mathrm{HCO}_{3}{ }^{-}$(Fig. 3B-C), indicating that the additive effect is lost at higher $\mathrm{HCO}_{3}{ }^{-}$concentrations. Furthermore, at $2.5 \mathrm{~mm}$ total mixtures, it seems that there was no significant $\mathrm{Na}^{+}$effect when its proportion was less than 0.5 (Fig. 3A), suggesting that low concentrations of $\mathrm{Na}^{+}(1.25 \mathrm{~mm})$ did not affect plant growth and that SDW was affected exclusively by $\mathrm{HCO}_{3}{ }^{-}$.

Despite no observed additive effect at high alkalinity, it is possible to estimate the detrimental effect of $\mathrm{HCO}_{3}{ }^{-}$on SDW using the predictions of the respective models. In Expt. 1, the decrease resulting from the pure $\mathrm{HCO}_{3}{ }^{-}$effect was of $-0.30 \mathrm{~g}$ per mM $\mathrm{HCO}_{3}{ }^{-}$; this represents a $5.9 \%$ decrease per mM $\mathrm{HCO}_{3}{ }^{-}$. In Expt. 2, the decrease resulting from the pure $\mathrm{HCO}_{3}{ }^{-}$effect at $2.5 \mathrm{~mm}$ was $-0.56 \mathrm{~g}$ per mм $\mathrm{HCO}_{3}^{-}$; at $5 \mathrm{~mm}$, the decrease was $-0.33 \mathrm{~g}$ per $\mathrm{mm}^{-} \mathrm{HCO}_{3}{ }^{-}$; and at $7.5 \mathrm{~mm}$, the decrease was $-0.19 \mathrm{~g}$ per $\mathrm{mM} \mathrm{HCO}_{3}{ }^{-}$. These figures represent a decrease of $12.7 \%$, $7.8 \%$, and $4.2 \%$ when $\mathrm{HCO}_{3}{ }^{-}$concentration was $2.5 \mathrm{~mm}, 5 \mathrm{~mm}$, and $7.5 \mathrm{~mm}$, respectively. In Expt. 3, there was a decrease in SDW when $\mathrm{HCO}_{3}{ }^{-}$concentration was $3.75 \mathrm{~mm}$ or more, which was of $0.62,0.60$, and $0.47 \mathrm{~g}$ per mм $\mathrm{HCO}_{3}{ }^{-}$at $3.75 \mathrm{~mm}, 5.65$ $\mathrm{mm}$, and $7.5 \mathrm{~mm}$, respectively. The figures from Expt. 3 represent a decrease of $11.0 \%, 10.7 \%$, and $8.2 \%$, per $\mathrm{mm}$ $\mathrm{HCO}_{3}{ }^{-}$at $3.75,5.65$, and $7.5 \mathrm{~mm}$, respectively. These SDW decrease rates attributable exclusively to $\mathrm{HCO}_{3}{ }^{-}$suggest a concentration-dependent effect because they tended to be higher at lower $\mathrm{HCO}_{3}^{-}$concentrations and lower at higher $\mathrm{HCO}_{3}^{-}$ concentrations (Fig. 5). This tendency may explain the lack of additive effects when the concentration of $\mathrm{HCO}_{3}{ }^{-}$was high.

\section{Conclusions}

The effect of the counter-cations should be considered when investigating the response of plants to alkalinity because they affect the SDW when combined with $\mathrm{HCO}_{3}{ }^{-}$. This is particularly important at low $\mathrm{HCO}_{3}^{-}$concentration because the separation of the counter-cation effect $\left(\mathrm{Na}^{+}\right)$from the $\mathrm{HCO}_{3}{ }^{-}$ effect was possible only when the toxicity resulting from the combination of both was additive, which was observed when

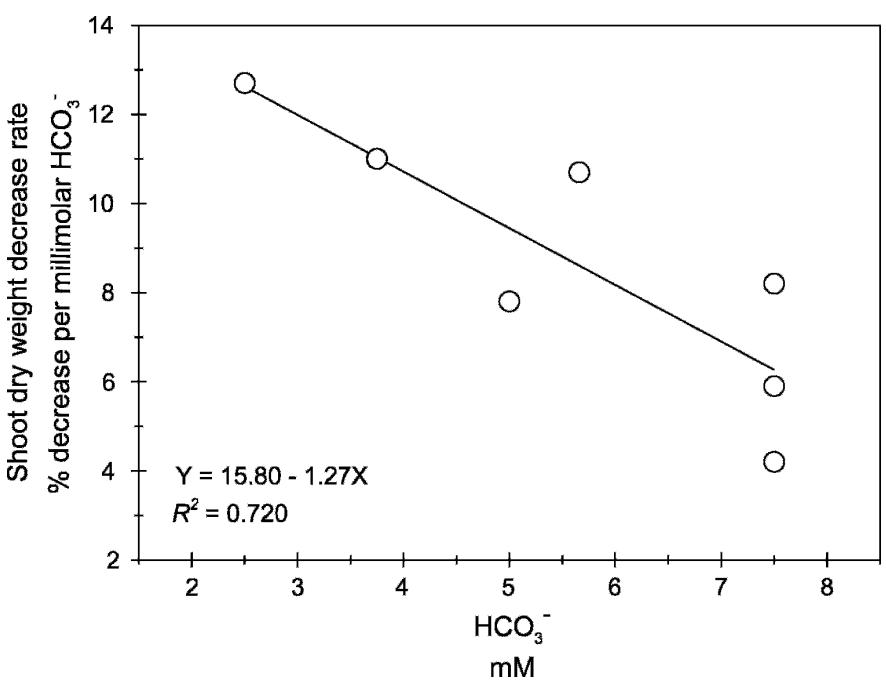

Fig. 5. Effect of increasing $\mathrm{HCO}_{3}{ }^{-}$concentration on the decreasing effect rate on shoot dry weight of 'Poncho' bean (Phaseolus vulgaris).

$\mathrm{HCO}_{3}{ }^{-}$was $3.75 \mathrm{~mm}$ or less. At this concentration, there was a $3.7 \%$ decrease in SDW per millimolar $\mathrm{Na}^{+}$and an $11.0 \%$ decrease per millimolar $\mathrm{HCO}_{3}{ }^{-}$.

\section{Literature Cited}

Alcántara, E., F.J. Romera, and M.D. de la Guardia. 1988. Genotypic difference in bicarbonate-induced iron chlorosis in sunflower. J. Plant Nutr. 11:65-75.

Alhendawi, R.A., V. Römheld, E.A. Kirkby, and H. Marschner. 1997. Influence of increasing bicarbonate concentration on plant growth, organic acid accumulation in roots and iron uptake by barley, sorghum, and maize. J. Plant Nutr. 20:1731-1753.

Bertoni, G.M., A. Pissaloux, P. Morad, and D.R. Sayag. 1992. Bicarbonate- $\mathrm{pH}$ relationship with iron chlorosis in white lupine. J. Plant Nutr. 15:1509-1518.

Bould, C., E.J. Hewitt, and P. Needham. 1984. Diagnosis of mixed disorders in plants. Vol. 1: Principles. Chemical Publishing, New York, NY.

Campbell, S.A. and J.N. Nishio. 2000. Iron deficiency studies of sugar beet using an improved sodium bicarbonate-buffered hydroponic growth system. J. Plant Nutr. 23:741-757.

Cornell, J.A. 2002. Experiments with mixtures. Designs, models, and the analysis of mixture data. 3rd Ed. Wiley, New York, NY.

Kaya, C., D. Higgs, and A. Ikinci. 2002. An experiment to investigate ameliorative effects of potassium on salt and alkalinity stressed vegetable crops. J. Plant Nutr. 25:2545-2558.

Marschner, H. 1995. Mineral nutrition of higher plants. 2nd Ed. Academic Press, San Diego, CA.

Matkin, O.A. and F.H. Petersen. 1971. Why and how to acidify irrigation water. Amer. Nurserymen 133:14, 73.

McCallister, D.L., R.A. Wiese, and N.J. Soleman. 1989. Effect of potassium salts on alleviation of lime-induced chlorosis in soybean. J. Plant Nutr. 12:1153-1174.

Navarro, J.M., V. Martínez, and M. Carvajal. 2000. Ammonium, bicarbonate and calcium effects on tomato plants grown under saline conditions. Plant Sci. 157:89-96.

Nikolic, M. and R. Kastori. 2000. Effect of bicarbonate and Fe supply on Fe nutrition of grapevine. J. Plant Nutr. 23:1619-1627.

Norvell, W.A. and M.L. Adams. 2006. Screening soybean cultivars for resistance to iron-deficiency in culture solutions containing magnesium or sodium bicarbonate. J. Plant Nutr. 29:1855-1867.

Nyholm, N.E.I. and G. Tyler. 2000. Rubidium content of plants, fungi and animals closely reflects potassium and acidity conditions of forest soils. For. Ecol. Mgt. 134:89-96. 
Pearce, R.C., Y. Li, and L.P. Bush. 1999a. Calcium and bicarbonate effects on the growth and nutrient uptake of burley tobacco seedlings: Hydroponic culture. J. Plant Nutr. 22:10691078.

Pearce, R.C., Y. Li, and L.P. Bush. 1999b. Calcium and bicarbonate effects on the growth and nutrient uptake of burley tobacco seedlings: Float system. J. Plant Nutr. 22:1079-1090.

Qi, J., J.D. Marshall, and K.G. Mattson. 1994. High soil carbon dioxide concentrations inhibit root respiration in douglas fir. New Phytol. 128:435-442.

Shi, D. and Y. Sheng. 2005. Effect of various salt-alkaline mixed stress conditions on sunflower seedlings and analysis of their stress factors. Environ. Exp. Bot. 54:8-21.
Shi, D. and D. Wang. 2005. Effects of various salt-alkaline mixed stresses on Aneurolepidium chinense (Trin.) Kitag. Plant Soil 271:15-26.

Sudharmai, C.R. and P. Padmaja. 1997. Effect of substitution of potassium by sodium on the chlorophyll content, stomatal characteristics and relative water content in cassava. J. Root Crops 23:81-85. Tanji, K.K. 1990. Nature and extent of agricultural salinity, p. 1-17. In: Tanji, K.K. (ed.). Agricultural salinity assessement and management. Amer. Soc. Civil Engineers, New York, NY.

Welfare, K., T.J. Flowers, G. Taylor, and A.R. Yeo. 1996. Additive and antagonistic effects of ozone and salinity on the growth, ion contents and gas exchange of five varieties of rice (Oryza sativa L.). Environ. Pollut. 92:257-266. 